\title{
PEMBELAJARAN BAHASA ARAB DI LINGKUNGAN PESANTREN DAN LUAR \\ PESANTREN
}

Muhammad Rasyid Ridho

STAI Ali bin Abi Thalib Surabaya

\begin{abstract}
الملنخص
إن اللغة العربية من المواد الهامة في عملية التعليم عند المدارس الدينية والمعاهد الإسلامية، إلا أن هناك بعض الاختلاف بين تعليم اللغة العربية في المعاهد والمدارس. هذا البحث سيتكلم عن تعليم اللغة العربية في المعاهد الإسلامية والمدارس العامة، وأخذ الباحث البيانات من المصادر العلمية المتعلقة في تعليم اللغة العربية العامة وتعليم اللغة العربية في المعاهد الإسلامية خاصة. والنتيجة من هذا البحث أن الاختلاف بين تعليم اللغة العربية في المعاهد والمدارس يقع من الأوجه الشتى كال المنهاج الدراسي، والكتب المقررة وكفاءة المدرسين.
\end{abstract}

Kata Kunci: Pembelajaran, Bahasa Arab, Pondok Pesantren

\section{PENDAHULUAN}

Pembelajaran bahasa Arab di Indonesia sekarang ini sudah tidak asing lagi bagi para penuntut ilmu, terutama bagi para penuntut ilmu Agama, karena Agama islam ini dilandaskan oleh Quran dan hadis, yang dimana keduanya tertulis menggunakan bahasa Arab, dan tidak akan bisa dipahami tanpa mempelajari bahasa Arab terlebih dahulu. Oleh karena itu para penuntut ilmu agama sangat dituntut untuk memahami bahasa Arab terlebih dahulu.

Saat ini di Indonesia sudah memiliki banyak sekali lembaga pendidikan bahasa Arab, mulai dari pondok pesantren, al Madrasah al Ibtidaiyyah, al Madrasah al Thānawiyyah dan al Madrasah al 'A'Aliyah, bahkan sampai ke jenjang perkuliahan. Terlepas dari itu semua, setiap lembaga pendidikan bahasa Arab tentu memiliki kurikulum yang berbeda- beda antara yang satu dengan yang lainnya.

Pembelajaran bahasa Arab di lembaga-lembaga yang bercorakkan pesantren lebih berhasil jika dibandingkan dengan pembelajaran bahasa Arab di lembaga pendidikan non pesantren, hal ini disebabkan karena dunia pesantren identik dengan dunia keilmuan Islam yang menjadikan kitab-kitab berbahas Arab sebagai literasi yang utama, dismping itu pembiasaan berbahasa Arab atau penggunaan bahasa Arab lebih mudah dibandingkan dengan lembaga non pesantren, ditambah lagi tenaga pendidik yang memahami bahasa Arab bukan hanya guru atau ustadz pengajar bahasa Arab.

Adapun pembelajaran bahasa Arab di lembaga non pesantren tentunya banyak mengalami kesulitan, selain kemampuan peserta didik yang tidak merata juga kurikulum pembelajaran bahasa Arab yang kurang tepat juga menjadi kendala utama.

Dari uraian di atas, pemakalah tertarik untuk membahas tentang pembelajaran bahasa Arab di dalam lingkungan pesantren dan di luar lingkungan pesantren. Karena pembelajaran bahasa Arab saat ini berkembang cukup pesat. Penelitian ini menggunkan literasi-literasi penelitian ilmiah seperti hasil penelitian yang dipublikasikan di jurnal-jurnal ilmiah terlebih jurnal-jurnal yang ditulis dengan tema pendidikan bahasa Arab.

\section{PEMBAHASAN}

\section{A. Pengertian Pembelajaran}


Pembelajaran berasal dari kata "ajar", yang kemudian menjadi sebuah kata kerja berupa "pembelajaran". Pembelajaran sebenarnya merupakan aspek kegiatan manusia yang kompleks, yang dimana hal tersebut tidak dapat sepenuhnya dijelaskan dengan detail. Adapun maksud dari pembelajaran secara sederhana adalah produk interaksi berkelanjutan antara pengembangan dan pengalaman hidup. Dalam makna yang lebih kompleks, hakikat dari pembelajaran adalah usaha sadar dari seorang guru untuk membelajarkan siswanya. ${ }^{1}$

Proses pembelajaran adalah suatu usaha untuk membuat siswa belajar. Sehingga situasi tersebut merupakan peristiwa belajar ( event of learning) yaitu usaha untuk terjadinya perubahan tingkah laku dari siswa. Perubahan tingkah laku dapat terjadi karena adanya interaksi antara siswa dengan lingkungannya. ${ }^{2}$

Menurut Gagne yang dikutip oleh Nazaruddin dalam bukunya Manajemen Pembelajaran bahwa istilah pembelajaran diartikan sebagai seperangkat acara atau peristiwa eksternal yang dirancang untuk mendukung terjadinya proses belajar yang sifatnya internal. Pengertian ini menunjukkan bahwa pembelajaran adalah proses yang sengaja dilakukan dan dirancang sedemikian rupa dalam rangka memberikan bantuan bagi terjadinya proses belajar. ${ }^{3}$

Dari beberapa definisi tentang pembelajaran di atas dapat disimpulkan bahwa pembelajaran adalah suatu proses belajar yang sengaja dilakukan, bertujuan untuk merubah pola pikir pelajar dan tingkah laku mereka.

\section{B. Pengertian Bahasa Arab}

Bahasa merupakan suatu hal yang sangat penting di dalam kehidupan manusia, karena dengan adanya bahasa, setiap individu dapat berinteraksi dengan yang lainnya, mereka bisa bertukar informasi antara yang satu dengan yang lainnya, tidak dapat dipungkiri juga dengannya manusia dapat mengutarakan keinginan mereka, dengannya pula manusia bisa menjalin sebuah $u k h u w a h$ islamiyah yang baik.

Di dalam kitab Mudkhal Ila Ilmi Al-Lughoh, Muhammad Ali al-Khauli mendefinisikan bahasa sebagai berikut:

1. Bahasa adalah sebuah sistem yang mampu menghubungkan antara dua pihak.

2. Bahasa adalah sebuah sistem yang digunakan untuk menukarkan ide, perasaan dan lainnya diantara manusia.

3. Bahasa adalah sarana untuk mengekspresikan kebutuhan, pendapat dan fakta diantara manusia.

4. Bahasa adalah simbol vokal yang digunakan untuk bertukar ide maupun perasaan diantara anggota dengan bahasa yang sama. ${ }^{4}$

Sedangkan dalam bahasa Arab, kata "لغة" berawal dari kata "لغا" yang artinya berbicara. Secara umum bahasa adalah suatu lambang yang berwujud bunyi, yang keluar dari mulut dalam bentuk sedemikian rupa, hinnga bunyi itu mengandung dan mempunyai arti tertentu yang digunakan oleh segolongan masyarakat tertentu untuk berkomunikasi dan berinteraksi. ${ }^{5}$

Ulin Nuha menukil tulisan dari Syaikh Mustafa Al-Ghalayaini di dalam bukunya yang berjudul jami' ad-Durus al-Arabiyah, bahwasanya bahasa Arab adalah kalimat-kalimat yang pergunakan oleh orang-orang Arab untuk mengungkapkan tujuan-tujuan (pikiran dan perasaan) mereka. ${ }^{6}$

Bahasa memiliki karakteristik yang unik dan universal, dikatakan unuik karena bahasa arab itu memiliki ciri khas yang memebedakannya dengan bahasa-bahasa yang lainnya, sedangkan

\footnotetext{
${ }^{1}$ Ulin Nuha, Ragam Metodologi Dan Media Pembelajaran Bahasa Arab, (Yogyakarta: Diva Press, 2016$), 143$.

2 Sunhaji," Konsep Manajemen Kelas Dan Implikasinya Dalam Pembelajaran”. Vol.02, No.02(2014), 32-33

${ }^{3}$ Nazaruddin, Manajemen Pembelajaran, (Yogyakarta: Teras, 2007), 24.

${ }^{4}$ Muhammad Ali Al- Khauli, Mudkhol Ila Ilmi Al-Lughoh.( Urdun: Dar Al- Falah, 1993), 12.

${ }^{5}$ Ulin Nuha, Ragam Metodologi dan Pembelajaran Bahasa Arab. (Yogyakarta: Diva Press, 2016), 23.

${ }^{6}$ Ibid., 25
} 
universal berarti adanya kesamaan yang dimiliki oleh bahasa lainnya. ${ }^{7}$ Karakteristik bahasa Arab sangatlah banyak, antara lain dapat diuraikan sebagai berikut:

1. Bahasa Arab memiliki ragam bahasa, yang meliputi:

a) Ragam sosial atau sosiolek yaitu ragam bahasa yang menunjukkan perbedaan penduduk dalam tutur katanya.

b) Ragam geografis yaitu ragam bahasa yang menunjukkan letak geografis penutur antara satu daerah dengan daerah lainnya, sehingga melahirkan dialek yang beragam.

c) Ragam idiolek yaitu ragam bahasa yang menunjukkan sifat kepribadian setiap individu masyarakat(lahjah al-fardiyyah)

2. Bahasa Arab dapat diekspresikan secara lisan ataupun tulisan.

3. Bahasa Arab memiliki system, aturan dan perangkat yang tertentu.

4. Bahasa Arab berpotensi untuk berkembang, produktif, kreatif, karena perkembangan bahasa selalu mengikuti perkembangan peradaban manusia, sehingga muncul istilah-istilah bahasa yang baru diantara kita.

5. Bahasa Arab memiliki sistem bunyi yang khas.

6. Bahasa Arab memiliki sistem tulisan yang khas.

7. Bahasa Arab memiliki struktur kata yang bisa berubah dan bereproduksi.

8. Bahasa Arab memiliki sistem I'rab. ${ }^{8}$

\section{Prinsip-Prinsip Pembelajaran Bahasa Arab}

Di dalam pembelajaran bahasa Arab setidaknya ada lima prinsip yang harus diperhatikan oleh setiap individu baik pendidik maupun peserta didik, yaitu:

1. Prinsip Prioritas

Di dalam pembelajaran bahasa Arab tentu memiliki prioritas, yang dimaksud dengan prioritas dari bahasa Arab di sini adalah mengajarkan, mendengarkan, dan bercakap sebelum menulis, mengajarkan kalimat sebelum mengajarkan kata, dan menggunakan kata-kata yang lebih akrab dengan kehidupan sehari-hari sebelum mengajarkan bahasa sesuai dengan kaidahkaidah yang berlaku.

Keterampilan mendengar dan berbicara lebih didahulukan sebelum menulis ataupun membaca, Karena para ahli berasumsi bahwasanya pengajaran bahasa yang baik adalah pengajaran yang sesuai dengan perkembangan bahasa yang dialami oleh manusia pada umumnya, yaitu setiap anak akan mengawali perkembangan bahasanya dari mendengar dan memperhatikan kemudian menirukan dari apa yang perhatikan tersebut. Hal ini menunjukkan bahwa kemampuan mendengar/menyimak harus lebih dulu dibina, kemudian kemampuan menirukan, lalu aspek lainnya seperti membaca dan menulis. ${ }^{9}$

2. Prinsip Korektifitas

Prinsip ini diterapkan ketika sedang mengajarkan materi الترانب (fonetik), الأصوت (sintaksis), dan المعاني (semiotik). Maksud dari prinsip ini adalah seorang guru tidak hanya menyalahkan peserta didiknya, tetapi dia juga harus melakukan pembetulan dan membiasakan peserta didik untuk kritis dalam pengajaran fonetik, sintaksis, dan semiotik. ${ }^{10}$

\section{Prinsip Berjenjang}

Jika dilihat dari sifatnya, setidaknya ada tiga kategori di dalam prinsip berjenjang ini. Yaitu, pergeseran dari yang kongkrit ke yang abstrak, dari yang global menuju yang universal, dan dari yang sudah diketahui ke yang belum diketahui. Ada kesinambungan antara apa yang

\footnotetext{
${ }^{7}$ Zulhannan, Teknik Pembelajaran Bahasa Arab Interaktif, (Jakarta: Rajawali Press, 2004),12.

${ }^{8}$ Ulin Nuha, Ragam Metodologi Dan Pembelajaran Bahasa Arab. ( Yogyakarta: Diva Press, 2016), 36-43.

9 Jabal Nur, ” Prinsip Dasar Metode Pembelajaran Bahasa Arab”, Vol.6, No. 1 (2013), 48-49.

10 Jabal Nur, ”Prinsip Dasar Metode Pembelajaran Bahasa Arab”, Vol.6, No. 1 (2013), 48-49.
} 
telah diberikan sebelumnya dengan apa yang akan diajarkan selanjutnya, dan ada peningkatan bibit pelajaran yang dulu dengan yang selanjutnya, baik jumlah jam maupun meterinya. ${ }^{11}$

4. Prinsip Pembelajaran Kebermaknaan

Prinsip pembelajaran kebermaknaan meyakini pentingnya faktor ini dalam belajar untuk menjadikan peserta didik menyerap pelajaran secara lebih lama dari pada belajar secara hafalan. Misalnya, dalam mengajar kosa kata maupun gramatika, guru sebaiknya mengajarkannya secara konteks. ${ }^{12}$

5. Prinsip Pujian atau Imbalan

Prinsip pujian atau imbalan menegaskan bahwa manusia secara universal terdorong untuk melakukan sesuatu karena ada imbalannya. Keampuhan imbalan, baik dalam prilaku binatang maupun manusia sudah terbukti. Contohnya, seekor lumba-lumba atau anjing yang cerdik di dalam pentas sirkus mau melakukan apa yang perintahkan oleh pawangnya semata-mata karena ada imbalannya yaitu makanan. Guru seringkali lupa akan hal ini, sehingga mereka kebanyakan kikir dalam memberi reward dalam bentuk pujian yang sebenarnya pada kontekskonteks tertentu diperlukan. ${ }^{13}$

\section{Pengertian Lingkungan Pendidikan}

Pendidikan merupakan masalah yang sangat penting dalam kehidupan. Pendidikan bersifat mutlak adanya bagi manusia. Pendidikan tidak bisa dipisahkan atau dilepaskan dari kehidupan manusia dalam berbangsa dan bernegara, karena pendidikan merupakan kebutuhan bagi manusia.

Pendidikan memiliki unsur-unsur penting di antaranya adalah lingkungan. Agar kita dapat membentuk lingkungan pendidikan yang Islami maka, kita harus mengetahui makna dari lingkungan pendidikan terlebih dahulu.

Lingkungan pendidikan adalah suatu institusi atau kelembagaan dimana pendidikan itu berlangsung. Lingkungan tersebut akan mempengaruhi proses pendidikan yang berlangsung. Dalam beberapa sumber bacaan kependidikan, jarang dijumpai pendapat para ahli tentang pengertian lingkungan pendidikan Islam. ${ }^{14}$

Wartono menukil dari tulisan Abuddin Nata di dalam bukunya yang berjudul Metodologi Studi Islam bahwa kajian lingkungan pendidikan Islam (tarbiyyah islamiyyah) biasanya terintegrasi juga secara mutlak dengan pembahasan mengenai macam-macam lingkungan. namun demikian, dapat dipahami bahwa lingkungan pendidikan islam adalah suatu lingkungan yang didalamnya terdapat ciri-ciri ke-Islaman yang memungkinkan terselanggaranya pendidikan islam dengan baik. ${ }^{15}$

\section{E. Pembelajaran Bahasa Arab di dalam Lingkungan Pondok Pesantren}

Pesantren merupakan suatu bentuk pendidikan keislaman yang sangat melembaga di Indonesia. Setiap pesantren pastinya memiliki ciri masing-masing yang dipengaruhi oleh pribadi para pendiri dan pemimpinnya. Pesantren sering disebut dengan istilah "pondok pesantren", hal ini di karenakan setiap pelajar tinggal atau menetap di pesantren selama mereka menempuh masa pembelajaran. Kata pondok (kamar, gubuk, rumah kecil) dipakai dalam Bahasa Indonesia dengan menekankan kesederhanaan bangunan. Kata pondok berasal dari bahasa Arab yaitu "funduq" yang berarti ruang tidur, wisma, atau hotel sederhana. Kata pesantren berasal dari kata santri yang mendapat imbuhan pe-an, yang memiliki arti tempat, maka pesantren adalah tempat para santri. ${ }^{16}$

Dalam mempelajari bahasa asing sekurang-kurangnya seseorang harus berusaha keras untuk menguasai apa yang terdapat di dalam bahasa tersebut. Termasuk penguasaan unsur kebudayaan baru, cara berfikir yang baru, serta cara bertindak yang baru pula. Keterlibatan secara menyeluruh baik fisik, intelektual maupun emosional sangat diperlukan agar dapat berhasil sepenuhnya dalam

\footnotetext{
${ }^{11}$ Ibid., 50.

12 Ibid.

13 Ibid.

${ }^{14}$ Sudiyono, Ilmu Pendidikan Islam Jilid 1, (Jakarta: Rineka Cipta, 2009), 298.

${ }^{15}$ Wartono, " Membentuk Lingkungan Pendidikan yang Islami”, Vol. II, (2013), 399-400

${ }^{16}$ Mohammad Siddiq, "Pembelajaran Bahasa Arab di Pondok Pesantren Daarunnajah,” Al-Ma'rifah, Vol. XIV. No. 2. (2017), 30.
} 
mengungkapkan dan menerima pesan melalui media bahasa kedua. Pembelajaran bahasa kedua bukanlah merupakan suatu kegiatan yang dapat di program dalam waktu yang singkat, tetapi merupakan suatu proses yang terdiri atas variabel-variabel yang tak terbatas. ${ }^{17}$

Di setiap pondok pesantren pasti memiliki kegiatan-kegiatan yang hampir sama dalam mengajarkan bahasa Arab kepada para santrinya, kegiatan manajemen pondok pesantren biasanya dikelola secara individual dengan nuansa kharismatik dan masih menggunakan pola pikiran yang lama. Perlu mempertimbangkan berbagai persoalan yang muncul sebagai akibat arus globalisasi.

Mudir harus mampu mengoptimalkan lembaga dan sumber daya manusia serta persoalanpersoalan yang ada di sekitar. Mudir harus memperhatikan beberapa faktor dibawah ini:

1) Faktor Internal

Faktor internal mencangkup keseluruhan kehidupan pondok pesantren yang dapat dikendalikan oleh Mudir, yang meliputi: Visi dan Misi pondok pesantren, tujuan yang ingin dicapai, perencanaan yang baik, serta implementasi pelaksanaan sistem program yang tepat dan strategi yang tepat pula. ${ }^{18}$

2) Faktor Eksternal

Faktor eksternal merupakan faktor lingkungan sekitar, di mana podok pesantren berdiri tegak. Yang meliputi: kebijakan pemerintah dari tingkat pusat sampai tingkat daerah, kebiasaan masyarakat, karena pondok pesantren didirikan untuk kepentingan masyarakat juga.

Dengan demikian Mudir sebuah pondok pesantren harus bisa merencanakan, mengelola, memberi pelayanan, dan membangun kerjasama yang baik dengan masyarakat, terlebih lagi dengan wali santri. Agar dapat mendidik santri yang berkualitas. ${ }^{19}$

Pola manajemen pembelajaran yang terdapat di pondok pesantren pada umumnya masih berbentuk pembelajaran klasikal dan kemadrasahan, walaupun sudah ada sebagian pondok pesantren yang menggunakan bentuk pembelajaran modern, dengan penerapan beberapa metode pembelajaran diantaranya:

a) Metode Halaqoh

Halaqoh, yang arti bahasanya adalah lingkaran murid atau sekelompok santri yang belajar di bawah bimbingan musyrif, atau belajar bersama dalam satu tempat. Metode ini di maksudkan sebagai penyajian bahan pelajaran dengan cara santri membahasnya bersama-sama, melalui tukar pendapat tentang suatu topik atau permasalahan. Musyrif atau Ustadz di sini bertindak sebagai “moderator". Metode ini bertujuan agar santri aktif dalam belajar. Melalui metode ini, akan tumbuh dan berkembang pemikiran-pemikiran kritis, analitis, dan logis. ${ }^{20}$

b) Metode Hafalan

Metode hafalan yang diterapkan dipondok pesantren pada umumnya dipakai untuk kitab-kitab tertentu. Seperti al-qur'an, baik surat-surat pendek maupun secara keseluruhan. Biasanya di metode ini para santri akan diberi tugas untuk menghafal beberapa ayat dari al-qur'an. Setelah beberapa hari barulah setiap sanri menyetorkan hafalannya ke musyrifnya. ${ }^{21}$

c) Pemberian Kosa Kata

Kegiatan ini adalah kegiatan yang dimana para santri akan diberikan kosa kata tambahan dari para asatidzah yang berupa fi'il (kata kerja) atau isim (kata benda). Pada

\footnotetext{
17 Ibid.

${ }^{18}$ Wahyu Setyabudi, Manajemen Program Pembelajaran Bahasa Arab di Pondok Pesantren, Tesis ( Malang: Universitas Islam Negeri Malang, 2018), 85.

${ }^{19}$ Ibid.

${ }^{20}$ Ibid., 86

21 Ibid.
} 
kegiatan ini yang paling berperan ialah bagian bahasa pusat yang sudah bekerja sama dengan bagian bahasa asrama dan mudabbir kamar. ${ }^{22}$

d) Metode Hiwar / Muhadatsah

Muhadatsah adalah kegiatan yang berisikan simulasi percakapan sehari-hari, yang dilakukan oleh para santri. Kegiatan ini biasanya dilakukan pada pagi hari, secara bergantian oleh setiap kelompok secara terjadwal. Tujuan dari kegiatan ini adalah untuk melatih santri agar terbiasa melakukan percakapan yang komunikatif dengan menggunakan bahasa Arab.

Pada kegiatan ini bagian bahasa pusat sangat berperan penting dalam membimbing para santri. Para santri dipasang-pasangkan, kemudian secara bergantian mereka saling bercakap-cakap dengan menggunakan bahasa Arab. ${ }^{23}$

e) Disiplin bahasa

Dalam kegiatan sehari-hari, dari mulai bangun tidur hingga tidur kembali, seluruh santri diwajibkan untuk menggunakan bahasa Arab saat berkomunikasi. Meskipun hal tersebut tidak dapat dilaksanakan seratus persen, namun kegiatan ini terus diupayakan untuk tetap dilaksanakan. Guna melatih kemampuan berbahasa santri.

Selain itu terdapat pula slogan-slogan yang berisi motivasi bagi para santri untuk selalu berbahasa Arab yang disematkan di lingkungan pondok. Terdapat pula lombalomba yang berkaitan dengan bahasa Arab, seperti pembacaan syai' $r$, drama berbahasa Arab, membaca berita dengan menggunakan bahasa Arab. ${ }^{24}$

\section{F. Pembelajaran Bahasa Arab di luar Lingkungan Pondok Pesantren}

Bahasa Arab merupakan bahasa Asing yang belum dikenal oleh peserta didik sejak kecil. Tetapi, pembelajaran bahasa Arab sebagai bahasa asing mempunyai berbagai prinsip. Prinsip tersebut adalah persamaan persamaan antara bahasa asing dengan bahasa ibunya akan memberikan pengaruh terhadap kemudahan dalam pembelajaran bahasa asing tersebut. Begitu juga sebaliknya, perbedaan-perbedaan yang terdapat pada bahasa ibu dan bahasa asing akan menimbukan kesulitan-kesulitan dalam mempelajari bahasa Arab sebagai bahasa asing.

Proses kemajuan berbahasa atau mempelajari bahasa Arab bagi orang Indonesia sangat tergantung pada dua faktor. Pertama, tingginya perbedaan dan persamaan antara bahasa mereka dengan bahasa Arab yang sedang dipelajarinya. Kedua, seberapa jauh siswa memberikan pengaruh terhadap proses mempelajari bahasa Arab. ${ }^{25}$

Pembelajaran bahasa Arab di lingkungan pondok pesantren dengan non pesantren tentu sangatlah berbeda. Dapat ditinjau dari banyak segi, baik dari segi pengajaran, kehidupan seharihari, dan juga muqorror yang digunakan.

Bahasa Arab merupakan satu disiplin ilmu yang terdiri dari berbagai aspek keterampilan utama di dalamnya. Aspek keterampilan utama tersebut meliputi keterampilan mendengar (maharah al-istima'), keterampilan berbicara ( maharah al-kalam), keterampilan membaca (maharah al- qira'ah) dan keterampilan menulis ( maharah kitabah). Keempat keterampilan tersebut merupakan keterampilan bahasa yang saling berurutan dan berkaitan. ${ }^{26}$

Orang yang belajar bahasa Arab akan mudah menguasai bahasa Arab apabila dia memulainya dengan melatih keterampilan-keterampilan tersebut secara berurutan, yang dimulai dari keterampilan mendengar, berbicara, dan seterusnya. Demikian juga dia akan menemukan kesulitan untuk benar-benar memiliki kemampuan berbahasa Arab yang baik dan benar, apabila

\footnotetext{
${ }^{22}$ Mohammad Siddiq, "Pembelajaran Bahasa Arab di Pondok Pesantren Daarunnajah, ” Al-Ma'rifah, Vol. XIV. No.2.(2017).82.

23 Ibid., 33.

${ }^{24}$ Mohammad Siddiq, "Pembelajaran Bahasa Arab di Pondok Pesantren Daarunnajah,” Al-Ma'rifah, Vol. XIV. No. 2. (2017), 83.

${ }^{25}$ Ulin Nuha, Ragam Metodologi dan Pembelajaran Bahasa Arab. ( Yogyakarta: Diva Press, 2016), 51.

${ }^{26}$ Mohammad Thoha, "Pembelajaran Bahasa Arab dengan Pendekatan Mamanajemen Berbasis Sekolah", Vol. 01, (2012), 82.
} 
dia mempelajari bahasa tidak dengan mengikuti sistematika keterampilan yang harus dia kuasainya. $^{27}$

Untuk membantu pelajar agar dapat dengan mudah menguasai masing-masing dari keterampilan tersebut. Seorang pelajar harus mampu memilih materi atau topik pelajaran yang sesuai dengan kesenangan dan pengalaman siswa. Di sisi lain pilihan metode dan strategi pembelajaran yang disesuaikan dengan keadaan siswa. ${ }^{28}$

Secara realita, Departemen Agama telah menetapkan kebijakannya bahwa pendidikan bahasa Arab diberikan kepada jenjang pendidkan dasar dan pendidikan menengah dan telah dituangkan dalam peraturan Menteri Agama Republik Indonesia No. 2 tahun 2008 tentang standar kompetensi lulusan dan standar isi pendidikan agama islam dan bahasa Arab di madrasah. ${ }^{29}$

Agar lingkungan non pesantren dapat berfungsi memberikan pemerolehan atau wacana bahasa, maka kegiatan pembelajaran di dalam kelas hendaknya menerapkan gabungan pendekatan komunikatif, quantum, dan kontekstual sebagaimana diuraikan sebagai berikut:

1. Menggunakan strategi interaksionis yang bertumpu pada kegiatan-kegiatan komunikatif bukan manipulatif, dan tidak terfokus pada penjelasan kaidah-kaidah.

2. Menggunakan materi yang bervariasi dengan memperbanyak bahan-bahan otentik dan memperhatikan prinsip-prinsip kebermaknaan, keterpakaian, dan kemenarikan.

3. Memperluas input kebahasaan bagi siswa dengan penugasan membaca buku, majalah, Koran berbahasa Arab, menonton film berbahasa Arab, dan sebagainya.

4. Memberikan peran yang dominan kepada siswa untuk berkomunikasi. Guru "tidak banyak bicara" tapi mengarahkan dan memfasilitasi.

5. Sedapat mungkin menggunakan bahasa Arab, meskipun penggunaan bahasa Indonesia dalam keadaan tertentu tidak ditabukan.

6. Menggunakan metode yang relevan dan teknik-teknik yang bervariasi tapi tidak bertentangan dengan pendekatan yang telah ditetapkan.

7. Merancang dan menyelenggarakan berbagai kegiatan penunjang, seperti latihan menulis insya' harian, latihan pidato, muhadatsah, wawancara, dan sejenisnya. ${ }^{30}$

Dari dua jalur pendidikan di atas tentu memiliki sangat banyak perbedaan, tetapi di sini saya akan menyebutkan beberapa perbedaan yang pernah saya alami, di antaranya:

1. Dalam pendidikan pesantren kurikulumnya dapat ditentukan dan dibuat sendiri tanpa mengikuti standar yang ditentukan oleh pemerintah, sedangkan non pesantren harus mengikuti standar yang dibuat oleh pemerintah.

2. Dalam pendidikan pesantren pengajarannya mampu mengembangkan metode-metode baru dalam menanamkan konsep maupun mempraktekkan langsung, sedangkan non pesantren hanya memiliki metode pembelajaran yang disesuaikan dengan bidang studinya saja.

3. Dalam pendidikan pesantren masa pembelajarannya relatif lebih lama dan efisien karna tidak hanya terpaku kepada guru saja, tetapi dapat dan mampu untuk berbaur dengan santri lainnya agar tidak bosan, sedangkan non pesantren memiliki waktu yang sangat singkat dan kurang efisien karena hanya terpaku kepada buku panduan saja tanpa dipraktekkan.

4. Dalam pendidikan pesantren peluang untuk bisa berbahasa Arab sangat besar karena setiap kaidah baru yang didapatkan langsung dipraktekkan dengan teman sebayanya, sedangkan non pesantren peluang untuk bisa berbahasa Arab kecil karena tidak semua teman sebayanya di rumah mempelajari bahasa yang sama.

\section{KESIMPULAN}

${ }^{27}$ Ibid.

${ }^{28}$ Ibid.

${ }^{29}$ Shafruddin Tajuddin, “Pengembangan Model Pembelajaran Bahasa Arab Tingkat Sekolah Dasar Untuk Meningkatkan Kemampuan Berbahasa Arab Siswa”, Vol. 29, No. 02(2009), 208.

${ }^{30}$ Ahmad Fuad Effendy, Metodologi Pengajaran Bahasa Arab. (Malang: Misyikat, 2012), 225. 
Dari pemaparan di atas dapat kita simpulkan :

$>$ Lingkungan pendidikan adalah suatu institusi atau kelembagaan dimana pendidikan itu berlangsung. Lingkungan tersebut akan mempengaruhi proses pendidikan yang berlangsung. Dalam beberapa sumber bacaan kependidikan, jarang dijumpai pendapat para ahli tentang pengertian lingkungan pendidikan Islam.

Pondok pesantren adalah tempat dimana bahasa Arab dapat berkembang dengan pesat. Tentunya didukung oleh faktor-faktor yang kuat diantaranya, lingkungan pondok itu sendiri yang dimana setiapa pondok membiasakan santrinya untuk berbahasa setiap waktu dengan menggunakan bahasa Arab, dan juga menerapkan beberapa metode seperti, halaqah, muhadatsah, hafalan, pemberian kosa kata, dan disiplin bahasa.

$>$ Pembelajaran bahasa Arab dilingkungan pondok pesantren dengan non pesantren tentu sangatlah berbeda. Dapat ditinjau dari banyak segi, entah dari segi pengajaran, kehidupan sehari-hari, dan juga muqorror yang digunakan.

$>$ Agar lingkungan non pesantren dapat berfungsi memberikan pemerolehan atau wacana bahasa, maka kegiatan pembelajaran di dalam kelas hendaknya menerapkan gabungan pendekatan komunikatif, quantum, dan kontekstual.

\section{DAFTAR PUSTAKA}

Al- Khauli, Muhammad Ali. 1993. Mudkhol Ila Ilmi Al- Lughoh. Urdun: Dar Al- Falah. Effendy, Ahmad Fuad. 2012. Metodologi Pengajaran Bahasa Arab, Malang: Misyikat.

Nazaruddin, 2007. Manajemen Pembelajaran, Yogyakarta: Teras.

Nuha, Ulin. 2016. Ragam Metodologi dan Media Pembelajaran Bahasa Arab, Yogyakarta: Diva Press.

Nur, Jabal. 2013. ” Prinsip Dasar Metode Pembelajaran Bahasa Arab”, Vol.6, No. 1.

Setyabudi. Wahyu. 2018. Manajemen Program Pembelajaran Bahasa Arab di Pindok Pesantren,

Tesis, Malang: Universitas Islam Negeri Malang.

Siddiq, Mohammad. 2017. "Pembelajaran Bahasa Arab di Pondok Pesantren Daarunnajah ," AlMa'rifah, Vol. XIV. No. 2.

Sunhaji. 2014. "Konsep Manajemen Kelas dan Implikasinya dalam Pembelajaran". Vol.02, No.02. Tajuddin, Shafruddin. 2009. "Pengembangan Model Pembelajaran Bahasa Arab Tingkat Sekolah Dasar Untuk Meningkatkan Kemampuan Berbahasa Arab Sisiwa”, Vol. 29, No. 02.

Thoha, Mohammad. 2012. "Pembelajaran Bahasa Arab dengan Pendekatan Mamanajemen Berbasis Sekolah", Vol. 01.

Wartono. 2013." Membentuk Lingkungan Pendidikan yang Islami”, Vol. II. Zulhannan. 2004. Teknik Pembelajaran Bahasa Arab Interaktif, Jakarta: Rajawali Press. 